\title{
ASPEK KE-SOEHARTO-AN DALAM KUMPULAN CERPEN SOEHARTO DALAM CERPEN INDONESIA
}

\author{
Burhan Nurgiyantoro \\ FBS Universitas Negeri Yogyakarta
}

\begin{abstract}
This research study aims to describe (1) the forms of Soeharto-related aspects and (2) ways of expressing those aspects in the anthology of short stories entitled Suharto claim Cerpen Indonesia.

The source of the research data was Soeharto dalam cerpen Indonesia (2001), an anthology of short stories edited by M. Shoim Anwar. All of the short stories (17) were selected. The data were collected through reading and recording techniques and were analyzed by the descriptive qualitative technique involving data comparison, categorization, tabulation, and inference. Data trustworthiness was assessed through the semantic and referential validities and data consistency through the intrarater technique.

Research findings show that 15 short stories clearly contain Soeharto-related aspects, and two short stories do not reveal these aspects clearly. Soeharto-related aspects are shown through: (1) personification in the form of physical appearance, character, verbal and nonverbal behaviors, (ii) governance and economic strategies, (iii) society's condition and attitude under his reign, approaching his fall and after his fall, (iv) spatial and temporal settings related to his reign, (v) the party functioning as his power apparatus, and (vi) government officials' life style and attitude. In general the short stories do not mention Soeharto directly, but only through certain aspects or symbols easily identified as Soeharto's characteristics. Soeharto-related aspects are expressed through various ways, such as parody, irony, cynicism, and dialectics. The expressions through particular characters parodying Soeharto are the most apparent, simultaneously using irony and cynicism. The expressions through irony are the most dominant in the short stories, and in this way the criticisms sound more subtle and "polite". This is different from cynicism, which criticizes and defames ones in a vulgar manner. This is a reflection of control imposed on the writers in the past, who now feel free to express anything without any fear of being arrested. The expressions through dialectics are made more intellectually and invite readers to think.
\end{abstract}

Key words: Soeharto-related aspects, personification, parody, irony, cynicism, dialectics

\section{A. Pendahuluan}

\section{Latar Belakang Masalah}

Sastra hadir karena memang diperlukan perannya dalam masyarakat, yaitu sebagai salah satu wujud ekspresi berkesenian, dan bahkan dalam hal tertentu dapat pula dipandang sebagai suatu bentuk "kontrol sosial". Dalam berbagai sastra dunia terlihat banyak karya sastra yang hadir dengan mengemban misi tersebut, misalnya karya sastra yang mengandung unsur 
kritik sosial. Sastra yang berisi kritik sosial memiliki fungsi "mengingatkan" akan adanya berbagai bentuk perilaku yang tidak sesuai dengan sifat-sifat kemanusiaan. Hal itu merupakan salah satu pertanggungjawaban moral karya sastra bagi masyarakat.

Salah satu ikon masyarakat Indonesia yang amat fenomenal adalah tokoh Suharto, mantan presiden Republik Indonesia, yang berkuasa selama kurang lebih 32 tahun, yaitu sejak tahun 1966 hingga 1998. Selama pemerintahannya, yang kini dikenal sebagai "diktator", terdapat berbagai bentuk kontroversi yang mencakup berbagai aspek kehidupan. Orangorang yang semula tidak berani bersuara karena takut keselamatannya terancam, setelah kejatuhannya beramai-ramai berteriak menghujat lewat berbagai kesempatan dan media. Misalnya, lewat demonstrasi, pidato di muka umum, tulisan di media massa, dan hujatan-hujatan lain yang sering disiarkan televisi. Demikian juga dalam wacana kesastraan, Suharto banyak dijadikan sumber inspirasi untuk dieksplorasi dan dieksploitasi secara kreatif-literer oleh para penulis. Eksplorasi dan eksploitasi Soeharto dalam teks-teks sastra bersifat khas kesastraan: misalnya dimunculkan sebagai tokoh imajiner, simbolistik, ironi, untuk sasaran "bulan-bulanan" baik secara "sembunyi-sembunyi" maupun terang-terangan.

Salah satu tulisan yang berangkat dari ikon Suharto itu adalah karya sastra yang bergenre cerita pendek yang dimuat di berbagai media massa. Sebagian dari cerpen tersebut kemudian dikumpulkan dalam buku kumpulan cerpen Soeharto dalam Cerpen Indonesia (M. Shoim Anwar, 2001). Buku ini menampilkan dua puluh buah cerpen yang ditulis oleh sejumlah pengarang, seperti Y.B. Mangunwijaya, Seno Gumira Ajidarma, Agus Noor, Bonari Nabonenar, dan lain-lam. Namun, setting cerita dan saat penulisannya sudah dilakukan sejak Suharto masih berkuasa, bukan hanya setelah kejatuhannya, sehingga tentunya dapat memperkaya personifikasi tokoh itu dan tafsir yang diberikan terhadapnya.

Pengumpulan cerpen-cerpen yang semula tersebar dalam berbagai media massa ke dalam sebuah buku yang khusus berdasarkan salah seorang tokoh nyata merupakan fenomena baru. Bahwa dewasa ini banyak tokoh penting, mulai dari kalangan politikus, selebritis, sampai olahragawan, beramairamai membukukan biodatanya sendiri, pengumpulan cerpen-cerpen dengan "sumber bahan" yang sama sehingga mirip dengan buku biografi ke dalam sebuah buku tetap saja menarik untuk ditanggapi. Apalagi tokoh yang diangkat adalah seorang yang amat dikenal di masyarakat dunia. Kehadiran buku tersebut dapat saja dipandang sebagai ikut menyemarakkan dan semakin memopulerkan Soeharto lewat tulisan ragam sastra dalam berbagai genre terlepas dari konotasi makna yang ditawarkan. Terlepas apakah karya-karya itu bernada menanjung, memuji, menyindir, mengritik, atau menghujat dengan caracara yang bagaimanapun tetap saja berfokus pada tokoh nyata Soeharto. Hal itu merupakan salah satu alasan yang cukup menarik untuk menjadikan kumpulan cerpen tersebut sebagai bahan kajian.

\section{Tujuan Penelitian}

Sesuai dengan permasalahan yang diteliti, penelitian ini bertujuan untuk (i) mendeskripsikan wujud penampilan aspek ke-Suharto-an dalam kumpulan cerpen Soeharto dalam Cerpen Indonesia, dan (ii) mendeskripsikan cara pengungkapan aspek ke-Suharto-an dalam kumpulan cerpen Soeharto dalam Cerpen Indonesia. 


\section{Landasan Teoretis}

a. Karya Sastra dalam Konteks Sosiologi sastra

Permasalahan apakah sastra sebagai cerminan realitas kehidupan sosial selalu menarik untuk dibicarakan. Karya sastra adalah sebuah fakta sosial yang dikreasikan oleh pengarang. Di pihak lain, pengarang yang adalah anggota masyarakat tertentu dan berinteraksi dengan orang-orang dari masyarakat lain yang masing-masing telah memiliki konvensi-konvensi dan adat kebiasaan tentulah mau tidak mau hal itu berpengaruh terhadap karya dihasilkan. Pengarang yang dibesarkan dalam suatu konvensi sosial tertentu secara tidak terelakkan, sadar atau tidak sadar, akan terpengaruh oleh kehidupan sosial budaya yang melingkupinya. Oleh karena itu, Chapman (1980: 26) mengungkapkan bahwa kelahiran karya sastra diprakondisi oleh kehidupan sosial budaya tempat pengarang hidup dan dibesarkan sehingga sikap dan pandangan hidup pengarang terhadap masalah yang dikisahkan dalam karyanya juga mencerminkan kehidupan sosial budaya masyarakatnya itu. Pandangan Chapman tersebut menunjukkan bahwa karya merupakan cermin realitas kehidupan sosial masyarakat yang dijadikan modelnya.

Dalam hal pemodelan tersebut Lotman (via Faruk, 1994: 47) mengatakan bahwa sastra merupakan sistem pemodelan tingkat kedua. Artinya, sastra merupakan sistem pemodelan yang ditumpangkan pada sistem pemodelan tingkat pertama, yaitu bahasa. Pemodelan itu sendiri menunjuk pada pengertian bahwa sastra merupakan suatu wacana yang memodelkan semesta yang tidak terbatas dalam satu semesta imajiner yang terbatas. Semesta (universe) dapat dipahami sebagai sebuah realitas kehidupan yang ada di dalam masyarakat, dan hal itulah yang dijadikan model dalam penciptaan dunia novel, dunia sastra. Culler (1975; Faruk, 1994: 47) mengatakan bahwa novel merupakan sebuah wacana yang di dalamnya dan lewatnya masyarakat mengartikulasikan dunia. Novel merupakan sebuah model tiruan kehidupan sosial tertentu, model personalitas individual, model hubungan antarindividu dalam suatu masyakarat, dan model signifikansi dari aspek-aspek dunia tersebut.

Sastra tidak pernah ditulis dalam situasi kekosongan budaya, tetapi muncul dari sebuah masyarakat yang telah memiliki tatanan kehidupan sosial. Tatanan inilah yang dijadikan model tiruan dalam penciptaan dunia sastra. Jadi, sastra bersifat "meniru" sesuatu yang telah bereksistensi sebelumnya, dan karenanya dalam batas-batas tertentu sastra dapat dipandang sebagai memparodikan sesuatu yang dijadikan modelnya tersebut. Dalam hal ini Margaret Rose (via Makaryk, 1995: 604), menyebut parodi sebagai "transcontextualized repetition" yang di dalamnya terdapat aspek pengulangan intertekstual dan ironi. Dengan demikian, pemodelan dalam teks-teks sastra, peniruan dan pengulangan terhadap sesuatu yang telah bereksistensi tersebut, dapat juga dikaitkan dengan teori intertekstual. Teks-teks yang dijadikan model, parodi, atau tiruan tersebut tidak hanya terbatas pada teks-teks tertulis saja, melainkan juga dapat diperluas dalam pengertian wacana realitas kehidupan sosial.

Intertekstualitas itu sendiri oleh Bakhtin (via Faruk, 1994: 134-37) dikelompokkan dalam teori dialogis dalam lingkup sosiologi sastra. Menurut Bakhtin tidak ada tuturan tanpa hubungannya dengan tuturan-tuturan yang lain. Hubungan dialogis adalah satu tipe khusus dari hubungan semantik yang bagian-bagiannya hams dibentuk 
oleh keseluruhan tuturan yang di baliknya berdiri subjek-subjek aktual dan potensial yaitu pengarangpengarang yang bersangkutan. Bakhtin antara lain membedakan wacana dialogis ke dalam wacana aktif dan pasif, tersurat dan tersirat. Wacana pasif menggunakan wacana yang terdahulu untuk ekspresinya seperti dalam parodi, sedang wacana aktif menempatkan wacana terdahulu tetap di luar dirinya meskipun berhubungan dengannya. Di pihak lain, wacana tersurat adalah wacana dengan kehadiran penuh atau dialog eksplisit, sedang wacana tersirat adalah wacana yang tidak terwujud secara material dan hanya tersedia dalam kenangan kolektif.

Sejarah menunjukkan bahwa ada perbedaan karakteristik karya sastra dalam menyikapi kiprah Soeharto yang dalam pemerintahannya otoriter dan antikritik. Ketika Soeharto masih berkuasa para pengarang tidak berani secara terang-terangan melancarkan kritik terhadapnya, kini setelah kejatuhannya mereka beramai-ramai mengritik dan menghujatnya tanpa takut dibredel atau ditangkap dengan tuduhan subversif. Dalam kondisi sebelum kejatuhan Soeharto, Emha (Faruk, 1994: 49-50) mengatakan bahwa konvensi sastra Indonesia dikuasai oleh konvensi "bisu" karena adanya larangan masuknya kenyataan sosial-politik ke dalam karya sastra karena dipandang dapat membahayakan. Konvensi sastra menjadi bersifat terikat dan cenderung menguntungkan pemerintah atau kaum establishment. Kini setelah kejatuhan Soeharto konvensi bisu tersebut tinggal sejarah dan konvensi yang independen yang memberi kebebasan berekspresi kepada pengarang sudah terbuka lebar.

\section{b. Cara Pengungkapan Gagasan da- lam Teks Kesastraan}

Kata-kata merupakan sarana strategis untuk menyampaikan dan mengkreasikan makna serta nada dan suasana penuturan. Nada (tone) dapat diartikan sebagai pendirian atau sikap pengarang terhadap pembaca dan (sebagian) masalah yang dikemukakan (Leech \& Short, 1984: 280). Sikap dan pendirian pengarang terhadap sesuatu tersebut dapat dibentuk, disiasati, dan diciptakan lewat pilihan kata-kata, bahasa, atau stile. Dengan kata lain, stile dipergunakan sebagai cara untuk mengungkapkan nada, sikap dan pendirian pengarang terhadap masalah yang diungkapkan kepada pembaca. Jadi, dilihat dari keperluan pengarang, stile dipergunakan sebagai salah satu cara mengungkapkan sikap dan pendiriannya terhadap sesuatu, sedang dilihat dari keperluan pembaca stile dapat dipakai sebagai sarana untuk mengenali dan mengidentifikasi sikap dan pendirian pengarang terhadap berbagai masalah yang diceritakan.

Dengan cara-cara yang dipilihnya tersebut pengarang ingin mengajak pembaca untuk melihat dan merasakan sesuatu sebagaimana dia melihat dan merasakannya, menafsirkan sesuatu sebagaimana dia menafsirkannya, dan menyikapi sesuatu sebagaimana dia menyikapinya.

Dengan cara-cara tersebut dia ingin berbagai pengalaman dengan pembaca sebagaimana ia merasakan pengalaman tersebut. Cara-cara tersebut dalam kesastraan oleh Stanton (via Nurgiyantoro, 2002: 25) disebut sebagai literary devices, 'sarana pengucapan kesastraan', sarana kesastraan. Macam sarana kesastraan yang dimaksud dapat berupa pemilihan stile, penggunaan simbolisme, ironi, sinisme, sudut pandang tertentu, dan lain-lain. Dengan demikian, sarana 
kesastraan merupakan sesuatu yang penting dalam rangka pencapaian efek tertentu pada teks-teks kesastraan dan karenanya perlu mendapat perhatian dalam penelitian.

Selain dengan cara-cara tersebut pengungkapan sesuatu dalam teks-teks kesastraan juga dapat berbentuk parodial, satins, dan dialektika (Hasanudin, 1998: 5). Cara-cara ini dilakukan untuk mencapai efek tertentu. Cara parodial merupakan suatu teknik pengungkapan dengan menirukan sesuatu dari orang lain, misalnya berupa gaya, karakter tokoh, cara-cara seseorang melakukan sesuatu, dan lain-lain. Dalam parodial biasanya terkandung unsur ironi sebagai bagian untuk mencapai efek tertentu. Karena bersifat peniruan dan di dalamnya terkandung unsur pengulangan, Margaret Rose (via Makaryk, 1995: 604), menyebut parodi sebagai "transcontextualized repetition" yang di dalamnya terdapat aspek pengulangan intertekstual dan iron. Ironi itu sendiri oleh Samuel Johnson (via Makaryk, 1995: 572) diartikan sebagai sebuah cara untuk mengemukakan sesuatu yang maknanya bertentangan dengan katakata yang dipergunakannya. Cara dialektik adalah pengungkapan sesuatu dengan menampilkan persoalan dan mengajak kita untuk ikut bernalar dengan dialog untuk menyelidiki suatu masalah, mengajak kita untuk memikirkannya secara logis dan teliti. Cara-cara tersebut akan dipergunakan sebagai bentuk klasifikasi cara-cara pengungkapan aspek ke-Soeharto-an yang dikaji dalam penulisan.

\section{B. Metode Penelitian}

Sumber data penelitian ini adalah cerpen-cerpen yang mengandung unsur ke-Soeharto-an dalam buku kumpulan cerpen Soeharto dalam Cerpen Indonesia (2001) editor M. Shoim Anwar yang seluruhnya betjumlah 17 buah. Cerpen- cerpen tersebut sebelumnya telah disiarkan baik lewat surat-surat kabar maupun berwujud buku kumpulan cerpen. Semua cerpen yang dijadikan sumber data. Adapun nama pengarang, judul cerpen, dan tahun pertama cerpen itu terbit dalam media massa sebagaimana diinformasikan dalam buku ditunjukkan sekaligus pada tabel hasuil penelitian.

Pengumpulan data dilakukan dengan teknik membaca dan mencatat. Teknik membaca dilakukan untuk mendapatkan data yang berwujud deskripsi verbal dari cerpen-cerpen yang bersangkutan. Analisis data dilakukan dengan mempergunakan teknik deskriptif kualitatif yang merupakan olah logika. Adapun kegiatan itu dilakukan dengan langkah-langkah: (i) pembandingan antardata: pembandingan semua deskripsi verbal per cerpen untuk memperoleh kategorikategori yang sejenis, (ii) kategorisasi: pengelompokan data-data ke dalam kategori-kategori yang sejenis sebagai hasil langkah sebelumnya, (3) penyajian data: penyajian data dilakukan dalam bentuk tabeltabel frekuensi pemunculan, namun pada prinsipnya tetap dilakukan dengan memakai pertimbangan logika, dan (4) pembuatan inferensi berdasarkan datadata hasil penelitian yang diperoleh.

\section{Hasil Penelitian dan Pembahasan \\ 1. Hasil Penelitian \\ a. Wujud Aspek Ke-Soeharto-an da- lam Kumpulan Cerpen Soeharto dalam Cerpen Indonesia}

Dari ke-17 buah cerpen yang dimuat dalam buku kumpulan itu terdapat 15 buah yang secara jelas, walau implisit, menampilkan aspek ke-Soeharto-an, sedangkan dua buah cerpen yang lain tidak secara jelas mengandung aspek ke-Soeharto-an. Wujud aspek ke-Soeharto-an yang ditemukan dalam tiap 
cerpen bermacam-macam sebagaimana yang ditunjukkan pada Tabel 1. Tetapi, jika dikelompokkan secara substansial mencakup: (1) personifikasi atau aspek kedirian, terutama dilihat secara ciri fisik dan karakter, (2) strategi pemerintahan, terutama dari segi secara politik dan ekonomi, (3) kondisi masyarakat, baik semasa masih berkuasa, menjelang jatuh, dan sesudah jatuh, (4) latar tempat dan waktu pemerintahan Soeharto, (5) partai, dan (6) sikap hidup dan gaya hidup pejabat teras masa pemerintahan Soeharto. Pemunculan keenam kategori tersebut dirangkum dalam Tabel 2.

Kedua cerpen yang tidak mengandung aspek ke-Soeharto-an itu adalah "Tembok Pak Rambo" (Taufik Ikram Jamil) dan "Masuklah ke Telingaku Ayah" (Triyanto Triwikromo). Bentuk personifikasi Soeharto dalam "Tembok Pak Rambo" tidak mudah dipahami lewat tokoh Pak Rambo yang hanya jendral berbintang tiga. Karakteristik yang dimiliki seperti orang besar, mempunyai ajudan, berkuasa, tetapi juga serakah, memiliki kekayaan dengan cara tidak benar, dan pemarah tidak dapat dikaitkan begitu saja dengan mantan Presiden Soeharto. Pengaitan Pak Rambo sebagai personifikasi Soeharto mungkin saja dapat dilakukan, tetapi bukan hanya Soeharto yang mempunyai ciri-ciri seperti Pak Rambo. Jadi, penafsiran Pak Rambo sebagai personifikasi Soeharto hanya merupakan salah satu bentuk penafsiran saja dan tidak terlalu kuat didukung oleh tanda-tanda semiotik secara eksplisit.

Demikian pula halnya dengan cerpen "Masuklah ke Telingaku Ayah". Data aspek ke-Soeharto-an tidak tampak dalam cerpen ini. Menyamakan tokoh Abilawa, yang diambil dari nama wayang Jagalabilawa, dengan Soeharto rasanya terlalu jauh walau Soeharto sendiri penggandrung wayang. Demikian juga menyamakan penyembelihan sapi-sapi oleh Abilawa sebagai simbolisasi pembantaian banteng yang lambang PDI, dan gadis kecil anak Abilawa yang berusia enam tahun, Shela, sebagai Tutut, anak Soeharto sulit un-

Tabel 1. Wujud Aspek Ke-Soeharto-an dalam Kumpulan Cerpen Soeharto dalam Cerpen Indonesia

\begin{tabular}{|c|l|l|l|}
\hline No. & \multicolumn{1}{|c|}{$\begin{array}{c}\text { Judul Cerpen } \\
\text { (Tahun Pertama } \\
\text { terbit) }\end{array}$} & \multicolumn{1}{|c|}{ Wujud Aspek Ke-Soeharto-an } & Keterangan \\
\hline 1. & $\begin{array}{l}\text { Menembak Banteng } \\
(1993)\end{array}$ & $\begin{array}{l}\text { 1) Strategi politik masa pemerintahan } \\
\text { Soeharto } \\
\text { 2) Gaya hidup pejabat teras }\end{array}$ & \\
\hline 2. & $\begin{array}{l}\text { Bapak Presiden yang } \\
\text { Terhormat (2000) }\end{array}$ & $\begin{array}{l}\text { 1) Personifikasi tokoh (fisik, karakter, } \\
\text { tingkah laku) } \\
\text { 2) Strategi pemerintahan }\end{array}$ & \\
\hline 3. & Paman Gober (1996) & $\begin{array}{l}\text { 1) Personifikasi tokoh (fisik, karakter, } \\
\text { tingkah laku) } \\
\text { 2) Strategi pemerintahan }\end{array}$ & $\begin{array}{l}\text { 1) Keadaan masyarakat Indonesia } \\
\text { 2) Strategi pemerintahan } \\
\text { 3) Latar waktu }\end{array}$ \\
\hline 4. & Diam (1996) & $\begin{array}{l}\text { Tidak ditemukan } \\
\text { Tembok Pak Rambo } \\
\text { (1996) }\end{array}$ & $\begin{array}{l}\text { Cerita dan unsur } \\
\text { tidak jelas } \\
\text { mengarah kepada } \\
\text { Soeharto }\end{array}$ \\
\hline
\end{tabular}




\begin{tabular}{|c|c|c|c|}
\hline No. & $\begin{array}{c}\text { Judul Cerpen } \\
\text { (Tahun Pertama } \\
\text { terbit) }\end{array}$ & Wujud Aspek Ke-Soeharto-an & Keterangan \\
\hline 6. & $\begin{array}{l}\text { Saran "Groot } \\
\text { Majoor" Prakosa } \\
\text { (1999) }\end{array}$ & $\begin{array}{l}\text { 1) Keadaan Jakarta akhir pemerintahan } \\
\text { Soeharto } \\
\text { 2) Strategi pemerintahan } \\
\text { 3) Latar waktu }\end{array}$ & \\
\hline 7. & $\begin{array}{l}\text { Bukan Titisan Semar } \\
\text { (1998) }\end{array}$ & $\begin{array}{l}\text { 1) Personifikasi tokoh (fisik, karakter, } \\
\text { tingkah laku) } \\
\text { 2) Situasi pemerintahan }\end{array}$ & \\
\hline 8. & Kaki Druhun (1998) & $\begin{array}{l}\text { 1) Personifikasi tokoh (fisik, karakter, } \\
\text { tingkah laku) } \\
\text { 2) Strategi ekonomi } \\
\text { 3) Partai } \\
\text { 4) Latar waktu }\end{array}$ & \\
\hline 9. & $\begin{array}{l}\text { Masuklah ke } \\
\text { Telingaku Ayah } \\
(2000)\end{array}$ & Tidak ditemukan & $\begin{array}{l}\text { Cerita dan unsur } \\
\text { tidak jelas } \\
\text { mengarah kepada } \\
\text { Soeharto } \\
\end{array}$ \\
\hline 10. & $\begin{array}{l}\text { Monolog Kesunyian } \\
\text { (1999) }\end{array}$ & $\begin{array}{l}\text { 1) Personifikasi tokoh (fisik, karakter, } \\
\text { tingkah laku) } \\
\text { 2) Strategi ekonomi }\end{array}$ & \\
\hline 11. & Celeng (2000) & $\begin{array}{l}\text { 1) Keadaan yang chaos } \\
\text { 2) Latar tempat tinggal } \\
\text { 3) Latar waktu }\end{array}$ & \\
\hline 12. & Senotaphium (1999) & $\begin{array}{l}\text { 1) Personifikasi tokoh (penamaan, } \\
\text { karakter, tingkah laku) } \\
\text { 2) Penamaan } \\
\text { 3) Latar waktu dan tempat }\end{array}$ & \\
\hline 13. & $\begin{array}{l}\text { Gadis Kecil dan } \\
\text { Mahkota Raja (2000) }\end{array}$ & $\begin{array}{l}\text { 1) Personifikasi tokoh } \\
\text { 2) Strategi Pemerintahan }\end{array}$ & \\
\hline 14. & $\begin{array}{l}\text { Menari di atas Mayat } \\
(2000)\end{array}$ & $\begin{array}{l}\text { 1) Personifikasi tokoh } \\
\text { 2) Strategi pemerintahan }\end{array}$ & \\
\hline 15. & Negeri Angin (2000) & $\begin{array}{l}\text { 1) Personifikasi tokoh } \\
\text { 2) Keadaan masa pemerintahan } \\
\text { Soeharto } \\
\text { 3) Latar waktu }\end{array}$ & \\
\hline 16. & $\begin{array}{l}\text { Puteri Jelita dan } \\
\text { Terbunuhnya Tuan } \\
\text { Presiden }(2000)\end{array}$ & $\begin{array}{l}\text { 1) Personifikasi tokoh (karakter, tingkah } \\
\text { laku) } \\
\text { 2) Straggetgi politik } \\
\text { 3) Balas dendam orang yang disakiti }\end{array}$ & \\
\hline 17. & Orang Besar (2000) & $\begin{array}{l}\text { 1) Kondisi masyarakat masa } \\
\text { pemerintahan Soeharto } \\
\text { 2) Kebijakan masa pemerintahan } \\
\text { Soeharto } \\
\text { 3) Latar waktu } \\
\text { 4) Sikap dan gaya pejabat } \\
\text { 5) Partai }\end{array}$ & \\
\hline
\end{tabular}

tuk dilakukan. Hasil penafsiran tersebut boleh jadi berbeda dengan penafsiran orang lain, misalnya editor kumpulan cerpen ini yang mengatakan ada aspek ke-Soeharto-an di dalamnya sehingga dimasukkan dalam buku ini. Adanya perbedaan penafsiran dalam sebuah teks kesastraan haruslah disikapi sebagai sesuatu yang wajar. 
b. Pengungkapan Aspek Ke-Soeharto-an dalam Kumpulan Cerpen Soeharto dalam Cerpen Indonesia

Pengungkapan aspek ke-Soehartoan dilakukan lewat beberapa cara, yaitu parodial, ironi, sinisme, dan dialektikal. Penggunaan keempat cara tersebut dalam cerpen-cerpen yang dikaji tidak sama frekuensi dan intensitasnya. Cara yang paling banyak dipergunakan secara berturut-turut adalah ironi, parodial, sinisme, dan dialektis. Cerpen mana saja yang mempergunakan satu atau beberapa cara pengungkapan yang dimaksud termasuk frekuensi penggunaannya secara lengkap dapat dilihat pada Tabel 3.

\section{Pembahasan Hasil Penelitian}

a. Aspek Ke-Soeharto-an dalam Kumpulan Cerpen Soeharto dalam Cerpen Indonesia

Ada banyak aspek yang dipergunakan untuk mengungkap dan menunjukkan unsur ke-Soeharto-an yang terlihat pada cerpen-cerpen yang dikumpulkan dalam buku Soeharto dalam Cerpen Indonesia tersebut. Soeharto yang dengan kekuasaannya membentang dalam sejarah Indonesia sejak tahun 1966 sampai dengan 1998 mempunyai daya tarik yang kuat untuk diungkap dan diangkat ke dalam teks-teks kesastraan. Kekuasaan Soeharto penuh dengan kontradiksi, penyalahgunaan kekuasaan, kesewenangan, represif, pelanggaran HAM berat, maraknya praktik korupsi, kolusi, dan nepotisme, dan paling mencolok adalah pemerkayaan keluarga sendiri, namun secara luar terkesan amat ramah, keba-

Tabel 2. Pemunculan Kategori Aspek Ke-Soeharto-an dalam Soeharto dalam Cerpen Indonesia

\begin{tabular}{|c|c|c|c|c|c|c|c|c|}
\hline \multirow[b]{2}{*}{ No. } & \multirow[b]{2}{*}{ Judul Cerpen } & \multicolumn{6}{|c|}{ Aspek Ke-Soeharto-an } & \multirow[b]{2}{*}{ Keterangan } \\
\hline & & $\begin{array}{l}5 \\
0 \\
0 \\
0 \\
0 \\
0\end{array}$ & 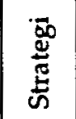 & $\begin{array}{l}\overrightarrow{\vec{w}} \\
\stackrel{\vec{z}}{\vec{z}} \\
\dot{0}\end{array}$ & 营 & 心 & 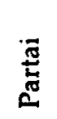 & \\
\hline 1. & Menembak Banteng & & $x$ & & & $x$ & & \\
\hline 2. & Bapak Presiden yang Terhormat & $\mathbf{x}$ & $x$ & & & & & \\
\hline 3. & Paman Gober & $\mathrm{x}$ & $x$ & & & & & \\
\hline 4. & Diam & & $x$ & $\mathbf{x}$ & $\mathbf{x}$ & & & \\
\hline 5. & Tembok Pak Rambo & & & & & & & \\
\hline 6. & Saran "Groot Majoor" Prakosa & & $x$ & $\vec{x}$ & $x$ & & & \\
\hline 7. & Bukan Titisan Semar & $x$ & $x$ & & & & & \\
\hline 8. & Kaki Druhun & $x$ & $x$ & & $x$ & & $x$ & \\
\hline 9. & Masuklah ke Telingaku Ayah & & & & & & & \\
\hline 10. & Monolog Kesunyian & $x$ & $x$ & & & & & \\
\hline 11. & Celeng & & & $x$ & $x$ & & & \\
\hline 12. & Senotaphium & $x$ & & $x$ & $x$ & & & \\
\hline 13. & Gadis Kecil dan Mahkota Raja & $x$ & $x$ & & & & & \\
\hline 14. & Menari di atas Mayat & $x$ & $x$ & & & & & \\
\hline 15. & Negeri Angin & $x$ & & $\bar{x}$ & $\mathrm{X}$ & & & \\
\hline 16. & $\begin{array}{l}\text { Puteri Jelita dan Terbunuhnya Tuan } \\
\text { Presiden }\end{array}$ & $x$ & $x$ & $x$ & & & & \\
\hline 17. & Orang Besar & & $\bar{x}$ & $x$ & $\bar{x}$ & $x$ & $x$ & \\
\hline & Jumlah (persen) & $\begin{array}{c}10 \\
(25)\end{array}$ & $\begin{array}{c}12 \\
(30)\end{array}$ & $\begin{array}{c}7 \\
(17.5)\end{array}$ & $\begin{array}{c}7 \\
(17,5)\end{array}$ & $\begin{array}{c}2 \\
(5)\end{array}$ & $\begin{array}{c}2 \\
(5)\end{array}$ & \\
\hline
\end{tabular}


pakan, dan familiar.

Sebenarnya, pemerintahan Soeharto bukannya tanpa prestasi karena banyak hal yang secara objektif bernilai positif bagi bangsa dan negara. Tetapi, yang muncul dan diangkat dalam karya sastra lebih banyak menyangkut dan menyoroti hal-hal yang dipandang negatif karena lewat sastra itu para pengarang sekaligus menyampaikan kritik. Selain itu, hal ini tampaknya ada kaitannya dengan unsur "balas dendam" para pengarang yang semula merasa dibatasi kreativitasnya, sebagaimana yang diungkapkan oleh Emha (via Faruk, 1994: 49). Pemerintahan Soeharto penuh penyimpangan dan penyalahgunaan kekuasaan, dan antikritik. Padahal, secara umum boleh dikatakan bahwa sastra justru lebih banyak menyuarakan sesuatu yang marginal, tertindas, tergusur, menjadi korban, terlanggar hakhaknya, dan lain-lain yang bersifat tidak menyenangkan. Oleh karena itu, begitu Soeharto jatuh sesuatu yang sebelumnya tidak terucapkan, kini dapat keluar dengan bebas ibarat air bah dari sebuah bendungan bobol.

Aspek ke-Soeharto-an yang terlihat meliputi banyak macam variannya (Tabel 1), dan secara substansial dapat dikategorikan ke dalam enam macam (Tabel 2). Aspek pertama, yang pemunculannya terbanyak kedua, adalah peng-

Tabel 3. Cara Pengungkapan Aspek Ke-Soeharto-an dalam Kumpulan Cerpen Soeharto dalam Cerpen Indonesia

\begin{tabular}{|c|c|c|c|c|c|c|}
\hline \multirow[t]{2}{*}{ No. } & \multirow[t]{2}{*}{ Judul Cerpen } & \multicolumn{4}{|c|}{$\begin{array}{c}\text { Cara Pengungkapan Aspek } \\
\text { Ke-Soeharto-an }\end{array}$} & \multirow[t]{2}{*}{ Keterangan } \\
\hline & &  & 릉 & 苞 & 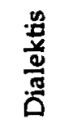 & \\
\hline 1. & Menembak Banteng & $x$ & $x$ & & & \\
\hline 2. & $\begin{array}{l}\text { Bapak Presiden yang } \\
\text { Terhormat }\end{array}$ & & $x$ & & & \\
\hline 3. & Paman Gober & $x$ & $x$ & $x$ & & \\
\hline 4. & Diam & $\mathbf{x}$ & $x$ & $x$ & & \\
\hline 5. & Tembok Pak Rambo & & & & & $\begin{array}{l}\text { Cerita dan unsur tidak jelas } \\
\text { mengarah kepada Soeharto }\end{array}$ \\
\hline 6. & Saran "Groot Majoor" Prakosa & & & & $x$ & \\
\hline 7. & Bukan Titisan Semar & $x$ & $x$ & $\bar{x}$ & & \\
\hline 8. & Kaki Druhun & $\bar{x}$ & $x$ & $x$ & & \\
\hline 9. & Masuklah ke Telingaku Ayah & & & & & $\begin{array}{l}\text { Cerita dan unsur tidak jelas } \\
\text { mengarah kepada Soeharto }\end{array}$ \\
\hline 10. & Monolog Kesunyian & $\bar{x}$ & $x$ & $x$ & & \\
\hline 11. & Celeng & $x$ & $x$ & $x$ & & \\
\hline 12. & Senotaphium & $\bar{x}$ & $x$ & $x$ & & \\
\hline 13. & Gadis Kecil dan Mahkota Raja & $x$ & $x$ & & & \\
\hline 14. & Menari di atas Mayat & $x$ & $x$ & $x$ & & \\
\hline 15. & Negeri Angin & $\bar{x}$ & $x$ & $x$ & & \\
\hline 16. & $\begin{array}{l}\text { Puteri Jelita dan Terbunuhnya } \\
\text { Tuan Presiden }\end{array}$ & $x$ & $x$ & $x$ & & \\
\hline 17. & Orang Besar & & $x$ & & & \\
\hline & Jumlah (persen) & $\begin{array}{c}12 \\
(33,3 \%)\end{array}$ & $\begin{array}{c}14 \\
(38.9)\end{array}$ & $\begin{array}{c}10 \\
(25)\end{array}$ & $\begin{array}{c}1 \\
(2,8)\end{array}$ & \\
\hline
\end{tabular}


gunaan bentuk personifikasi, baik yang menyangkut aspek fisik, karakter, penamaan, maupun citraan yang lain. Pemunculannya dalam cerpen dapat salah satu atau beberapa varian sekaligus, misalnya aspek penamaan dan karakter atau fisik dan karakter. Pelukisan aspekaspek tersebut terlihat terang-terangan, atau tidak langsung, tetapi mudah dipahami karena terdapat "kata-kata kunci" yang menunjukkan bahwa yang dimaksud adalah Soeharto. Penggunaan bentuk personifikasi Soeharto ditemukan dalam cerpen-cerpen "Bapak Presiden yang Terhormat", "Bukan Titisan Semar", "Kaki Druhun", "Paman Gober", "Monolog Kesunyian", dan lain-lain.

Satu-satunya aspek ke-Soehartoan dalam wujud penamaan ditemukan dalam cerpen "Senotaphium" (Agus Noor), yaitu yang memasang tokoh utama cerita Papa Hartanaga yang bertempat tinggal di Jalan Canderanasia. Papa Hartanaga dapat dengan mudah dikenali sebagai nama samaran Soeharto, dan itu diperkuat dengan latar tempat tinggal di Jalan Cendana yang disamarkan menjadi Jalan Canderanasia. Selain itu, juga disebut salah seorang nama jendralnya, yaitu Jenderal Wirenatopolus yang secara mudah dikenali sebagai Jenderal Wiranto, Menteri Pertahanan dan Keamanan pada saat menjelang kejatuhan Soeharto. Penggambaran tokoh yang secara fisik dan karakter memperlihatkan sifat kebapakan, senyumnya yang khas, ramah, dan penuh kearifan, pengayoman, pengertian, dan berbagai tingkah laku lain yang menunjukkan bahwa itu Soeharto, misalnya dapat dilihat pada cerpen "Bapak Presiden yang Terhormat" (Ages Noor) dan "Bukan Titisan Semar" (Bonari Nabonenar) sebagaimana terlihat dalam nukilan berikut.
Peang termangu-mangu di depan televisi, memperhatikan Bapak Presiden yang renyah ketika menjawab pertanyaan-pertanyaan petani, atau nelayan, atau orangorang cilik lainnya. Betapa menyejukkan senyum itu. Arif. Penuh pengayoman dan pengertian. Juga saat Bapak Presiden menyerahkan penghargaan Kalpataru yang disiarkan langsung televisi, Peang membayangkan kalau dirinya berada di deretan orangorang yang dapat penghargaan itu. Ia bayangkan namanya dibacakan, ia bayangkan dirinya melangkah pelan dan Bapak Presiden menyambutnya dengan senyum ramah, menjabat tangan dan menepuk-nepuk pundaknya.

(Soeharto dalam Cerpen Indonesia, 2001:11)

Maka, menjelang hari jadi desa yang kelima puluh sekian, dikumpulkanlah segenap dalang yang ada di seluruh desa, dan dikeluarkanlah perintah untuk menciptakan lakon: Titisan Kiai Semar. Ini menjadi proyek besar. Berhari-hari bersidang, para dalang itu ternyata belum juga menghasilkan lakon Titisan Kiai Semar.

(Soeharto dalam Cerpen Indonesia, 2001:57)

Contoh kutipan cerpen pertama mengungkapkan Soeharto yang seorang presiden itu lewat angan tokoh Peang, namun tidak secara jelas baik secara fisik maupun karakter menunjuk pada diri Soeharto. Sebaliknya, pada kutipan cerpen yang kedua jatidiri Soeharto hanya dapat dikenali lewat karaktemya yang menganggap dirinya sebagai titisan Semar dan permintaannya kepada para dalang untuk membuatkan lakon wayang. Pada pertengahan tahun 1990- 
an, tepatnya 1996, saat ulang tahun Negara Republik Indonesia yang ke51, Presiden Soeharto meminta kepada para dalang untuk menciptakan lakon wayang kulit dengan cerita Semar Babar Jati Diri (Nurgiyantoro, 1998:200). Jadi, peristiwa nyata tersebutlah yang diangkat ke dalam cerpen dengan mengganti tokoh Soeharto menjadi Kepala Desa Kadhungmakmur.

Di samping tokoh Kepala Desa Kadhungmakmur tersebut, tokoh Kaki Druhun dalam cerpen "Kaki Druhun" (Bonari Nabonenar) juga merupakan personifikasi Soeharto baik dilihat dari deskripsi fisik, karakter, maupun lingkungan (la tar) yang digambarkannya. Misalnya, adanya kata-kata: "Gelar baru pun diperolehnya: Pelopor Pembangunan Desa Kerebabar! Dan jangan lupa, sejak itulah buki yang angker itu diberi nama: Bukit Druhun" (Soeharto dalam Cerpen Indonesia, 2001:67). Gelar itu analogi dengan gelar yang diberikan kepada Soeharto, yaitu Bapak Pembangunan, sedang penamaan "Bukit Druhun" tersebut analogi dengan nama salah sebuah bukit di Indonesia yang diberi nama Bukit Soeharto.

Aspek ke-Soeharto-an kedua yang justru paling banyak ditemukan dalam cerpen-cerpen yang diteliti adalah unsur strategi terutama yang berwujud strategi politik, pemerintahan, dan managemen ekonomi. Masa pemerintahan Soeharto yang selama 32 tahun dan penuh dengan langkah-langkah represif, otoriter, pelaksanaan pemilu hanya bersifat simbolistis daripada sebagai ekspresi demokratis (Mcbeth \& Vatikiotis, via Baehaqi, 1999:5) yang hanya demi kelangsungan kekuasaan saja. Demikian juga masalah ekonomi yang hanya dikuasai oleh segelintir orang, yaitu keluarga dan kroninya. Kondisi tersebut diungkap dalam cerpen-cerpen pada umumnya tidak menyebut nama Soeharto atau pemerintahan Soeharto secara tegas, terutama pada karya-karya yang ditulis sebelum kejatuhannya. Tetapi, pembaca akan segera mengerti bahwa kondisi yang dimaksud adalah kondisi pemerintahan Soeharto karena terdapat sejumlah "tanda" yang menunjukkan ke arah itu secara jelas. Cerpen-cerpen yang menampilkan hal-hal tersebut aantara lain adalah "Menembak Banteng", "Diam", "Bukan Titisan Semar", "Kaki Druhun", "Paman Gober", "Monolog Kesunyian", "Orang Besar", dan lainlain.

Pada cerpen "Diam" (Moes Loindong) dikisahkan bahwa pada masa pemerintahan wayang, simbolisme Soeharto, rakyat dipaksa untuk diam menyaksikan kiprah pemerintahannya dantabu melontarkan kritik, dan jika tidak diam tentu akan berakibat kurang menyenangkan. Maka, "diam menjadi kepatuhan sosial yang merata, disebar rata, menjadi pemerataan keresahan.... Stabilitas kediaman harus dipertahankan demi keberhasilan dalang, melaksanakan pembangunan lakon" (Soeharto dalam Cerpen Indonesia, 2001:27). Strategi politik "mendiamkan" rakyat adalah salah cara yang ditempuh oleh Soeharto untuk mencapai stabilitas nasional. Rakyat tidak diberi hak untuk bersuara secara berbeda, semua harus seragam demi keberhasilan pembangunan. Kemungkinan adanya perubahan haruslah menunggu sekali dalam lima tahun, itu pun pada kenyataannya tidak terjadi.

Pemilu di Indonesia dilaksanakan lima tahun sekali, tetapi pelaksanaan pemilu sebagaimana dikemukakan di atas hanyalah purapra demokratis, bersifat simbolistik, dan hanya bertujuan untuk melanggengkan kekuasaan. Strategi politik untuk mempertahankan kekuatan itu diungkap dan dipertanyakan dalam cerpen "Paman Gober" (Seno Gumira Adjidarma). "Memang, 
Paman Gober adalah ketua terlama perkumpulan Unggas Kaya. Entah mengapa ia selalu terpilih kembali, meski pemilihan selalu berlangsung seolah-olah demokratis. Begitu seringnya ia terpilih, sampai-sampai seperti tidak ada talon yang lain lagi" (Soeharto dalam Cerpen Indonesia, 2001:22). Pemilu yang menjadi sarana ekspresi demokratis rakyat tetapi dimanipulasi oleh Soeharto -yang diparodikan dengan tokoh dunia bebek-kartun Paman Gober ciptaan Walt Disney- merupakan salah satu hal yang menarik dan banyak digugat di dunia nyata dan dijadikan sindiran dan sinisme di dunia fiksi.

Soeharto sendiri bukannya tidak mengerti jika terdapat banyak orang yang tidak lagi menyukai kepemimpinannya dan menghendaki mundur dari kedudukan presiden, tetapi orangorang yang bersikap demikian akan disingkirkannya. Sebaliknya, ia sering berkelit bahwa dirinya masih dibutuhkan rakyat, dan hasil pemilu itu yang dijadikan bukti konkret legitimasi dirinya. la bersikap munafik dengan merendah bahwa seandainya ada tokoh lain yang dapat menggantikannya, ia pun lebih suka melakukan aktivitas lain. Hal ini disindir secara sinis oleh Seno dalam "Paman Gober".

"Paman Gober," kata Donal suatu hari. "Mengapa Paman tidak mengundurkan diri saja, pergi ke pertanian seperti Nenek, menyepi dan merenungkan arti hidup? Sudah Waktunya Paman tidak terlibat lagi dengan urusan duniawi."

"Lho, aku mau saja Donal. Aku mau hidup jauh dari Kota Bebek ini. Memancing, main golf, makan sayur asem, dan membuka butirbutir falsafah hidup bangsa bebek. Tapi, apa mungkin aku menolak untuk dicalonkan? Apa mungkin aku menolak kehormatan yang diberi- kan segenap unggas? Terus terang, sebenarnya, sih, aku lebih suka mengurus peternakan.

(Soeharto dalam Cerpen Indonesia,

2001:24)

Soeharto memang memiliki usaha pertanian, perkebunan, dan peternakan yang sering dibanggakannya, terutama adalah peternakan sapi di Tapos. Tamutamu negara yang berkunjung ke Indonesia tidak jarang diajak untuk melihat usaha peternakannya tersebut. Setelah Soeharto jatuh tanah yang dikuasainya untuk peternakan tersebut diminta kembali oleh warga, para pemilik tanah sebelumnya, yang mengaku bahwa tanahnya diminta dengan paksa.

Jati diri Seharto juga diungkap dalam strategi ekonomi terutama strategi untuk memperkaya keluarga dan kroninya. Misalnya, masalah monopoli perniagaan cengkeh (BPPC, Badan Penyangga Pemasaran Cengkeh) yang dikelola oleh anak kesayangannya, Tomy Soeharto. Para petani dibujuk dan dipaksa hanya menjual cengkeh kepada BPPC dengan harga yang sangat murah, dan selanjutnya BPPC-lah yang menjual ke pabrik-pabrik rokok dengan harga yang tetap saja tinggi. Kebijakan itu sangat merugikan petani, dan sebaliknya semakin memperkaya Tomy, tetapi rakyat tidak berani protes. Petani yang tidak tahu dibujuk, seolah-olah ditolong dan diberi jalan keluar yang bagus dan menguntungkan. Hal itu diungkap dalam cerpen "Kaki Druhun" (Bonari Nabonenar): “... Tetapi jika nanti benar-benar berhasil, dan kita panen, jangan jual Ice mana-mana basil panen kita. Hanya itu syaratnya. Mengerti?" (Soeharto dalam Cerpen Indonesia, 2001:66).

Aspek ke-Soeharto-an selanjutnya terlihat dalam hal situasi dan kondisi masyarakat baik semasa berkuasa, ketikajatuh, maupun sesudah kejatuhannya. 
Artinya, eksistensi Soeharto dalam cerpencerpen yang bersangkutan dilihat dari tanda-tanda yang terdapat di dalam masyarakat. Tanda-tanda yang dimaksud dapat berwujud keadaan, sikap, perilaku, dan tindakan masyarakat yang secara langsung atau tidak langsung berkaitan atau dapat dikaitkan dengan Soeharto, baik semasa berkuasa, menjelang dan saat jatuh, serta masa sesudah kejatuhannya. Ada dua hal yang secara mencolok menunjukkan perbedaan keadaan dan sikap masyarakat di antara ketiga masa tersebut yang berwujud sikap, reaksi, perilaku, dan tindakan masyarakat. Keadaan itu pada umumnya juga terkait langsung dengan waktu penulisan cerpen tersebut, yaitu sebelum atau sesudah kejatuhan Soeharto. Cerpen-cerpen yang mengandung aspekaspek tersebut antara lain "Bapak Presiden yang Terhormat", "Diam”, "Paman Gober", "Celeng", "Saran 'Groot Majoor' Prakosa", "Senotapium", “Orang Besar", dan lain-lain.

Keadaan masyarakat ketika Soeharto masih berkuasa digambarkan sebagai sangat tertekan, tidak berani berbicara sebab jika berbicara takut dituduh sebagai subversif, hanya mampu menonton sang dalam pembangunan dengan tidak berdaya, dan hanya bisa diam karena diam dianggap dapat menciptakan stabilitas diungkap dalam cerpen "Diam" (Moes Loindong). Masyarakat lebih memilih diam demi keselamatan diri, walau hal itu bertentangan dengan kata hati, sambil menunggu kemungkinan adanya perubahan dalam lima tahun sekali. Tetapi, perubahan itu tidak pernah terjadi. Hal itu disebabkan, sebagaimana diungkap dalam cerpen "Paman Gober", pemilu hanya bersifat pura-pura daripada betul-betul sebagai pesta demokratis dalam arti yang sebenarnya dan lebih bertujuan untuk melanggengkan kekuasaan presiden. Oleh karena itu, orang yang sudah jenuh dengan kondisi pemerintahan hanya menginginkan satu berita: kapan Paman Gober (baca: Soeharto) meninggal. Berita itu selalu ditunggu setiap pagi begitu begitu mereka bangun tidur dan membaca koran.

Kondisi diam dan tertekan tersebut sangat kontras dengan keadaan masyarakat menjelang dan sesudah kejatuhan Soeharto. Masyarakat yang amat marah kepada Soeharto dan pemerintahannya seolaholah melakukan balas dendam dengan berbuat apa saja termasuk perilaku negatif. Keadaan masyarakat itu ibarat bendungan jebol yang kemudian melanda apa saja yang menghalangi. Pada intinya masyarakat menginginkan kebebasan yang selama tiga dekade tersumbat, menginginkan perubahan, dan reformasi di segala bidang. Keadaan masyarakat yang paling mencolok adalah adanya demonstrasi besar-besaran yang dipelopori oleh mahasiswa, demonstrasi yang semula menuntut pengunduran Soeharto sebagai presiden kemudian berkembang menjadi penuntutan dan pengadilan presiden Soeharto.

Aspek ke-Soeharto-an berikut yang terungkap dalam cerpen-cerpen itu adalah latar baik latar tempat maupun waktu. Latar tempat adalah tempat yang menunjukkan tempat kediaman Soeharto baik secara eksplisit maupun implisit, sedang latar waktu adalah saat yang menunjukkan atau dapat diidentifikasi sebagai menunjukkan keberadaan Soeharto. Cerpen-cerpen yang mengandung aspek ke-Soeharto-an kondisi masyarakat baik sebelum, semasa, maupun setelah kejatuhan Soeharto diatas dapat dipandang sebagai menunjukkan latar waktu keberadaan Soeharto. Misalnya, cerpen-cerpen "Bapak Presiden yang Terhormat", "Diam", "Paman Gober", "Celeng", "Saran 'Groot Ma- 
joor' Prakosa", “Senotaphium”, "Orang Besar", dan lain-lain. Selain menunjukkan latar waktu cerpen "Celeng" dan "Senotaphium" sekaligus juga memperlihatkan latar tempat.

Cerpen "Celeng" (Agus Noor)mengisahkan keresahan warga yang diteror oleh kemunculan celeng yang sering membunuh dengan menghisap darah bayi hingga mati kering. Masyarakat kemudian memutuskan untuk memburunya. Karena dicegat dan dibubarkan oleh aparat keamanan, mereka memilih lewat gorong-gorong untuk terus memburu celeng dan sampailah di kota besar yang penuh beton yang ternyata adalah Jakarta. Saat itu di Jakarta terjadi demonstrasi dan rombongan pemburu celeng termasuk yang dibubarkan. Rombongan yang tinggal 20 orang terus memburu celeng yang baunya semakin terasa menyentuk hidung. Bau celeng tercium semakin keras dari sebuah jalan, dan ketika nama jalan itu dibaca ternyata berbunyi: Jalan cendana. Jalan Cendana adalah jalan tempat kediaman Soeharto. Jadi, bau celeng itu berasal dari kediaman Soeharto, dan saat itu Soeharto baru panen demonstrasi.

Aspek ke-Soeharto-an dalam cerpen-cerpen itu juga terungkap lewat gaya para pemimpin semasa Soeharto berkuasa. Gaya yang dimaksud dapat berupa tingkah laku, tindakan, sikap yang bergaya hidup mewah, berfoyafoya, sok penting, beda antara apa yang diucapkan dan apa yang dilakukan, figur yang semestinya melayani masyarakat tetapi justru minta dilayani, dan lain-lain. Tingkah laku yang demikian adalah pemandangan yang biasa dan mudah ditemukan pada saat itu. Cerpen yang mengungkap aspek ke-Soeharto-an lewat sikap dan gaya hidup para pemimpin tersebut adalah "Menembak Banteng" (F. Rahadi) dan “Orang Besar" (Jujur Prananto). Cerpen
"Menembak Banteng" mengisahkan Jendral Pumawirawan Basudewo yang mempunyai hobi berburu mendapat order untuk menembak banteng dari menteri negara urusan satwa liar di Taman Nasional Ujung Kulon karena populasi banteng dinilai sudah terlalu banyak dan dikhawatirkan mengganggu eksistensi badak bercula satu. Setelah seharian berburu banteng, di tengah hutan itu malam harinya Basudewo makan daging panggang dengan nikmatnya dan anak buahnya pun bersuka ria. Jadi, para pemimpin itu di tempat yang tidak semestinya pun tetap saja menunjukkan gaya hidupnya yang mewah, padahal mereka baru saja membunuhi lawanlawan politiknya.

Dalam cerpen "Orang Besar" dikisahkan seorang warga desa yang kurang mampu yang dikejar-kejar hutang, yaitu Wasito, disanjungsanjung di depan warga kalurahan oleh Mulawarman yang dulu pemah berhutang tiga ekor kambing untuk disembelih dalam proyek filmnya. Wasito yang semula bermaksud menagih utang itu diancam Pak Lurah agar tidak menemui Mulawarman karena kini is telah menjadi orang besar dan bahkan menjadi calon bupati di daerah itu sehingga ulah Wasito itu dapat mempermalukannya. Namun, ternyata Mulawarman tidak memberi uang kepada Wasito sehingga ketika Carik Dirgono datang menagih hutang, Wasito tidak berani menemuinya lagi. Tokoh Mulawarman adalah sebagian gambaran pejabat yang turun ke daerah dan dipuja-puja oleh rakyat, orang atau pejabat pemerintah memuji-memuji peran rakyat secara munafik untuk kepentingannya sendiri, tetapi mereka rakyat kecil itu tetap saja dilupakan. Lurah Desa dan Carik Dirgono adalah cermin pejabat pemerintahan lebih rendah yang suka mencari muka kepada pejabat yang lebih tinggi untuk mencari selamat. 


\section{b. Pengungkapan Aspek KeSoeharto- an dalam Kumpulan Cerpen Soe- harto dalam Cerpen Indonesia}

Sebagaimana terlihat pada Tabel 3, pengungkapan aspek ke-Soeharto-an dilakukan lewat beberapa cara, yaitu parodial, ironi, sinisme, dan dialektis. Cara yang paling banyak dipergunakan secara berturut-turut adalah ironi, parodial, sinisme, dan dialektis. Namun, pada umumnya dalam satu cerpen dapat ditemukan lebih dari cara pengungkapan, misalnya cara parodial, ironi, dan sinisme sekaligus, atau yang lain, serta hanya satu cerpen yang diungkapan dengan cara, yaitu "Saran 'Groot Majoor' Prakosa" dengan cara dialektis.

Parodial adalah pengungkapan yang berintikan peniruan sesuatu dari orang lain, misalnya berupa gaya, karakter tokoh, cara-cara seseorang melakukan sesuatu, dan lain-lain. Itulah sebabnya di dalamnya peniruan itu terkandung unsur pengulangan dari sesuatu yang ditirunya. Cara parodial dalam cerpen-cerpen dalam kumpulan cerpen Soeharto dalam Cerpen Indonesia pada umumnya dimaksudkan untuk menampilkan tokoh-tokoh cerita yang memparodikan Presiden Soeharto. Atau sebaliknya, Soeharto ditampilkan lewat tokoh-tokoh cerita yang memparodikan jati dirinya. Tingkah laku Soeharto yang diparodikan itu dapat berwujud karakter, tindakan, gaya bicara, tampilan fisik, katakatanya, dan lain-lain yang biasanya telah dikenal orang sebagai khas milik Soeharto. Namun, dalam konteks cerpen itu Soeharto yang diparodikan itu sekaligus dalam pemaknaan ironis. Oleh karena itu, dalam kaitan ini Margaret Rose (via Makaryk, 1995: 604) sebagaimana dikemukakan, menyebut parodi sebagai "transcontextualized repetition" yang di dalamnya terdapat aspek pengulangan intertekstual dan ironi.
Tokoh-tokoh cerpen yang secara jelas terlihat diparodikan dari Soeharto itu misalnya adalah tokoh Paman Gober ("Paman Gober", Seno Gumira Ajidarma), Kepala Desa Kadhungmakmur ("Bukan Titisan Semar", Bonari Nabonenar), Kaki Druhun ("Kaki Druhun", Bonari Nabonenar), Jawad ("Monolog Kesunyian”, Indra Tranggono), Papa Hartanaga ("Senotaphium", Agus Noor), dan lain-lain. Sebagai tokoh cerita yang hidup dalam dunianya sendiri tentu saja tidak semua jati diri tokoh-tokoh tersebut diparodikan dari Soeharto. Jati diri ke-Soeharto-an yang diparodikan dalam diri para tokoh itu hanyalah berupa aspek-aspek tertentu baik yang berupa tindakan, kata-kata, maupun aspek-aspek yang lain.

Tokoh Paman Gober dikisahkan sebagai Ketua Perkumpulan Unggas Kaya yang amat kaya dan berkuasa, tetapi pelit dan kejam. Tetapi, herannya ia amat dicintai anak-anak sedunia. Orang yang berani mengecamnya justru tidak mendapat simpati. Ia selalu mengancam orang yang berani mengritiknya, maka hampir tidak ada orang yang berani mengitik. Sudah berpuluh tahun ia menjadi pemimpin negara, tetapi tidak ada yang dapat dan berani menggantikannya. Demokrasi berjalan, tetapi tidak memikirkan pimpinan karena memang hanya ada satu pimpinan. Setiap kali terpilih kembali, dengan berpura-pura ia menyesalkan mengapa tidak ada calon lain karena ia sudah amat tua. Ia bahkan sudah menyiapkan istana tempat untuk menguburnya kelak jika sudah mati.

Kisah tentang Paman Gober di atas, walau berkisah di dunia unggas dan dengan tokoh unggas pula, secara jelas merupakan kisah Soeharto. Gambaran tokoh yang sebagai ketua perkumpulan unggas, kaya dan amat berkuasa, kejam, sudah berpuluh tahun menjadi kepala negara, demokrasi semu, tidak ada 
orang yang berani mengritik, telah menyiapkan kuburan, dan lain-lain adalah sebagian jati diri Soeharto. Jadi, walau Paman Gober adalah tokoh unggas yang bermain di dunia unggas, ia adalah personifikasi dan sekaligus parodinya Soeharto. Cerpen ini syarat kritik, namun dengan mengambil tokoh binatang kritik yang disampaikan terasa menjadi tidak terlalu vulgar walau masih mudah dikenali dan sasaran yang dituju. Hal ini mengingat cerpen tersebut ditulis (1996) ketika Soeharto masih amat berkuasa. Jadi, unsur kehati-hatian masih dilakukan, dan Seno sendiri pada tulisan lain mengatakan bahwa ketika hati pers dan nurani dibungkam, maka cerita merupakan pilihan untuk berekspresi.

Tokoh Kaki Druhun juga merupakan parodinya Soeharto. Kaki Druhun dikisahkan sebagai tokoh yang sangat terpandang di desa Kerebabar. Di desa itu terdapat bukit Druhun, sebuah nama yang diambil dari nama Kaki Druhun. Ketika harga cengkeh naik, Kaki Druhun mengajak warga desa untuk menanam cengkeh, tetapi hasil cengkehnya nanti harus dijual kepadanya. Suatu ketika bukit itu terbakar habis dan yang tersisa tinggal pohon kemuning. Kaki Druhun terkejut dan mencoba memanjat bukit itu, tetapi jatuh dan tersangkut dahan pohon itu. Kini ia tinggal menjadi manusia tua yang rapuh. Orangorang yang semula membenci mulai berani bersuara dan menentang. Tetapi, para dhemit di bukit itu telah bertekad bulat untuk mengangkat Kaki Druhun menjadi raja dhemit. Gambaran jati diri Kaki Druhun tersebut secara mudah dikenali sebagai sebagian dari jati diri Soeharto. Penamaan Bukit Druhun misalnya, adalah analogi dengan nama Bukit Soeharto; Kaki Druhun yang jatuh tersangkut pohon kemuning adalah simbolisasi kejatuhan Soeharto yang masih terselamatkan oleh Golkar yang berwarna dasar kuning; para dhemit yang bertekad mengangkat Kaki Druhun adalah suara sebagian masyarakat waktu itu yang berkebulatan tekad mengangkat kembali Soeharto sebagai presiden yang kesekian.

Tokoh Paman Gober dan Kaki Druhun, juga Kepala Desa Kadhungmakmur, memiliki kesamaan karakter dan tingkah laku yang secara jelas diparodikan dari Soeharto. Ketiga tokoh ini sama-sama seorang kepala, yaitu kepala negara dan kepala desa. Ketiganya sama-sama ditakuti dan dibenci rakyat, antikritik, dan selalu terpilih kembali menjadi kepala pemerintahan. Paman Gober ditulis sebelum Soeharto jatuh, sedang Kaki Druhun dan Kepala Desa Kadhungmakmur setelah kejatuhan Soeharto, namun dalam hal parodi, ironi, dan nada sinisme yang dikandungnya kurang lebih sama.

Pengungkapan aspek ke-Soehartoan lewat ironi adalah cara yang paling banyak ditemukan selain cara parodial dan sinisme. Dalam banyak cerpen ketiga cara tersebut atau cara ironi dan sinisme ditemukan secara bersamaan. Artinya, dalam satu cerpen mengandung ketiga atau kedua cara itu sekaligus. Cara parodial yang memparodikan aspek keSoeharto-an dari segi yang negatif, pada umumnya sekaligus terkandung unsur ironi dan bahkan sinisme sekaligus. Hal itu misalnya terlihat dalam kutipan dari cerpen "Bukan Titisan Semar" berikut.

Maka Kepala Desa Kadhungmakmur itu jadilah seorang pemimpim berwajah dewa; namun sayangnya: berhati setan. Di mimbarmimbar resmi, dia bisa berkhotbah bak para dai. Di hadapan warga desa yang sedang bersedih, dia bisa menjadi penghibur. Dia bisa menjadi sangat dermawan, seperti halnya gembong lintah darat 
yang tiba-tiba juga bisa menjadi sangat dermawan, di hadapan para wartawan dan kamera televisi. Padahal, dia itu, tak kurang dan tak lebih adalah bangsat!

Dengan otot-ototnya yang kekar, sesungguhnya dia teramat lemah di hadapan wanita, terlebih jika wanita itu adalah istrinya sendiri. Dan di balik kedermawanannya, dia adalah seorang mahabajingan, yang kadang membagikan secuil dari hasil jarahannya kepada para korbannya.

Banyak warga desa yang menyadarinya, namun mereka masih juga memaafkannya, karena sebagian besar di antara mereka telah pula termakan keyakinan bahwa dia itu, Kepala Desa Kadhungmakmur, tak lain dan tak bukan adalah titisan Kiai Semar.

(Soeharto dalam Cerpen Indonesia,2001:56-7)

Sinisme masyarakat akan "keabadian" kepemimpinan Paman Gober, sedang mereka tidak berani bersuara, mengritik, apalagi menggugat, diwujudkan dengan penantian akan datangnya kematiannya. Kematian paman Gober merupakan berita yang paling ditunggu setiap hari. Hal itu adalah bentuk sinisme yang paling memuncak karena ekspresi yang lain dari warga yang amat membenci tetapi tak berdaya tidak lagi dimungkinkan. Jadi, yang ada hanyalah menunggu, menunggu berita kematian. Berita kematian adalah berita yang paling ditunggu. Sungguh, sebuah ironi yang amat sinis.

Semua bebek menunggu kematian paman Gober. Tiada lagi yang bisa dilakukan selain menunggununggu saat itu. Setiap kali penduduk Kota Bebek membuka koran, yang ingin mereka ketahui Cuma satu: apakah hari ini Paman Gober sudah mati. Setiap pagi mereka berharap akan membaca berita kematian Paman Gober di halaman pertama.

(Soeharto dalam Cerpen Indonesia, 2001:25)

Pengungkapan dengan cara ironi dilakukan dengan menuturkan sesuatu yang maknanya bertentangan atau tidak ada kesesuaian antara apa yang dilakukan dan dikatakan dengan keadaan yang sebenamya. Cara ini banyak dipergunakan dalam pengungkapan sesuatu dalam teks-teks kesastraan untuk mendialogkan sesuatu dengan pembaca dan pembaca pun dapat menerimanya dengan senyum-paham. Dengan demikian, dalam sebuah penuturan yang ironis sekaligus terkandung kritik, kritik yang disampaikan dengancara yang halus. Hal itu berbeda dengan cara sinisme, yang dapat dipandang sebagai kelanjutan ironi, yang mengandung kritik vulgar dan sarkastis sebagaimana dicontohkan di atas. Dengan cara ironi sesuatu yang dikritik terkesan lebih "sopan" karena tidak secara langsung menunjuk hidung. Namun, justru dengan cara itu sesuatu yang sebenamya dimaksudkan akan memberikan kesan yang lebih mendalam.

Cerpen yang secara kuat mengungkapkan sesuatu secara ironi adalah "Bapak Presiden yang Terhormat" (Agus Noor) dan "Orang Besar" (Jujur Prananto). "Bapak Presiden yang Terhormat" mengisahkan tokoh rakyat jelata, Peang, yang ingin mengadukan nasibnya yang kena gusur di kampungnya kepada Bapak Presiden. Peang memperoleh gambaran presiden sebagaimana yang sering dilihatnya di televisi tetangga: tokoh yang amat ramah, senyum yang menyejukkan, kebapakan, yang mau men- 
jawab berbagai pertanyaan dan keluhan petani seperti dalam Klompencapir, yang mempertemukan presiden dengan para petani seluruh tanah air, dan lain-lain yang serba baik. Dengan citra seperti yang diperolehnya itu, Peang yakin Bapak Presiden pasti mau menerima aduannya lewat surat yang dibawanya. Tetapi, fakta menunjukkan lain. Ia mustahil dapat menemuinya untuk memberikan surat. Semua orang sebenarnya sudah tahu hal itu, namun di sinilah letak ironinya. Gambaran yang tentang presiden yang diperolehnya lewat televisi itu sama sekali menyesatkan, tak ada sama sekali senyum keramahan dan sikap kebapakan. Artinya, keadaan itu ironis sekali.

Pengungkapan aspek keSoehartoan yang berikutnya adalah dengan cara dialektis. Cara pengungkapan sesuatu lewat dialektis adalah cara yang intelektual, yaitu dengan menyodorkan permasalahan untuk dikemudian dipecahkan. Permasalahan yang dimaksud diungkapkan lewat dialog atau cerita, lewat penalaran, dan kemudian mengajak kita untuk memikirkan bagaimana seharusnya menyikapi persoalan tersebut. Cara berpikir dialektis menurut Hegel misalnya, berpandangan bahwa selalu ada pertentangan dari dua persoalan yang menimbulkan adanya hal lain. Jadi, cara berpikir dialektis mengandaikan adanya dua persoalan yang bertentangan untuk kemudian ditemukan sesuatu yang dua hal tersebut.

Cerpen yang menampilkan cara dialektis hanya ditemukan dalam "Saran 'Groot Majoor' Prakosa" (YB. Mangunwijaya). Cerpen ini mengisahkan perjuangan para mahasiswa yang berdemonstrasi menuntut turunnya Soeharto dari kekuasaannya dan mereka dikejar-kejar aparat keamanan. Dalam pelarian menghindari aparat para demonstran bersembunyi di rumah
"Groot Majoor" Prakosa, seorang veteran perang kemerdekaan. Mbah Prakosa kemudian bercerita seputar perang kemerdekaan yang intinya adalah perjuangan yang akan dicapai harus dilakukan berdasarkan cara-cara konstitusional, bukan dengan cara liar. Segala sesuatu dapat dibicarakan, dimusyawarahkan lewat sidang parlemen sehingga segalanya mempunyai kerangka kerja yang jelas. Cerita Mbah Prakosa tersebut sebenarnya berupa sindiran kepada para demonstran yang lebih mengutamakan gerakan "liar" dan mengesampingkan cara-cara konstitusional, misalnya lewat sidang istimewa DPR/MPR. Pada prinsipnya cara damai yang konstitusional mestinya yang diutamakan, bukan dengan cara demonstrasi yang amat marak saat menjelang kejatuhan Soeharto. Mahasiswa pendemo yang mendengarkan cerita Mbah Prakosa pun mau mengerti. Jadi, dengan berpikir secara dialektis itu berbagai persoalan dipikirkan penyelesaiannya, termasuk penyelesaian peristiwa Soeharto yang panen demonstrasi kala itu.

\section{Kesimpulan}

(1) Dari ke-17 buah cerpen yang dimuat dalam buku kumpulan cerpen Soeharto dalam Cerpen Indonesia, editor M. Shoim Anwar (2001), ke-15 di antaranya secara jelas mengandung aspek ke-Soeharto-an, sedang dua buah yang lain kurang secara jelas mengandung aspek tersebut. Pengungkapan aspek ke-Soeharto-an, yang dimaksudkan sebagai halhal yang menunjukkan jati diri Soeharto, dalam cerpen-cerpen itu ditemukan lewat berbagai hal, yaitu lewat: (i) bentuk personifikasi baik secara fisik, karakter, maupun tingkah laku verbal dan nonverbal, (ii) strategi pemerintahan dan perekonomian, atau berbagai kebijakan semasa 
pemerintahan Soeharto, (iii) kondisi dan sikap masyarakat semasa berkuasa, menjelang, dan sesudah kejatuhan Soeharto yang berwujud berbagai perilaku dan tindakan tertentu yang mereaksi Soeharto, (iv) latar tempat dan waktu yang ada kaitannya dengan (kekuasaan) Soeharto, (v) partai, yaitu partai yang menjadi alat Soeharto untuk selalu berkuasa, dan (vi) gaya dan sikap hidup para pejabat semasa Soeharto. Pada umumnya cerpen-cerpen itu tidak menyebut nama Soeharto secara langsung, melainkan "hanya" lewat aspek-aspek tersebut atau simbol-simbol tertentu, tetapi gambaran yang terungkap secara jelas dan mudah dikenali sebagai jati diri Soeharto.

(2) Pengungkapan aspek ke-Soeharto-an dalam cerpen-cerpen tersebut dilakukan dengan cara-cara yang bervariasi, dan cara-cara yang ditemukan adalah lewat parodi, ironi, sinisme, dan dialektikal. Pengungkapan lewat tokoh-tokoh tertentu yang memparodikan Soeharto terlihat paling jelas dan mudah dikenali, dan sekaligus juga mengandung cara ironi dan sinisme. Pengungkapan dengan cara ironi yang banyak ditemukan dalam cerpen-cerpen itu, dan lewat cara ini unsur kritik yang ingin disampaikan terlihat menjadi lebih halus dan terkesan lebih "sopan". Hal itu berbeda dengan cara sinisme yang mengritik, atau bahkan menghujat, yang terkesan lebih vulgar dan terang-terangan. Hal itu bisa jadi merupakan refleksi keterkekangan para penulis selama ini untuk berekspresi yang kini merasa bebas untuk mengungkapkan apa saja tanpa takut ditangkap. Namun, pada umumnya dalam satu cerpen ditemukan lebih dari satu cara dalam mengungkapkan jati diri ke-Soeharto-an itu, dan yang paling banyak adalah cara parodial, ironi, dan sinisme tersebut. Pengungkapan dengan cara dialektis yang dilakukan secara lebih intelektual dan mengajak kita untuk berpikir hanya ditemukan dalam satu cerpen.

\section{Daftar Pustaka}

Baehaqi, Imam (Penyunting). 1999. Soeharto Lengser, Perspektif Luar Negeri. Yogyakarta: LKiS.

Chapman, Seymour. 1980. Story and Discourse, Narrative Structure in Fiction and Film. Itacha: Cornell University Press.

Faruk. 1994. Pengantar Sosiologi Sastra, dari Strukturalisme Genetik sampai Post-Modernisme. Yogyakarta: Pustaka Pelajar.

Hasanudin WS. 1998. "Pengaruh Mitos dalam Karya Sastra Indonesia Modern Warna Lokal Minangkabau", dalam Humanus, Vol.1, No.1, hlm. 1- 12.

Leech, Geoffrey N. dan Michael H. short. 1984. Style in Fiction, a Linguistic Introduction to English Fictional Prose. London: Longman.

Makaryk, Irena R. (ed). 1995. Encyclopedia of Contemporary Literary Theory, Approaches, Scholars, Terms. Toronto: University of Toronto Press.

Nurgiyantoro, Burhan. 2002. Transformasi Unsur Pewayangan dalam Fiksi Karya Indonesia. Yogyakarta: Gadjah Mada University Press. 